\title{
TOXICITY OF ${ }^{13} \mathrm{C}$-LABELED LINOLEIC AND LINOLENIC ACIDS FOR DIAGNOSTIC BREATH TESTS
}

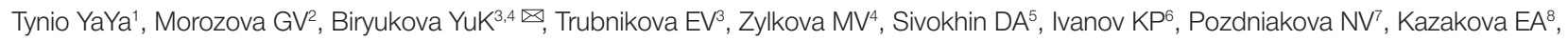
Mutnykh ES ${ }^{9}$, Shevelev $\mathrm{AB}^{9,10}$

${ }^{1}$ Russian State University of Physical Education, Sport, Youth and Tourism, Moscow, Russia

2 Skryabin Moscow State Academy of Veterinary Medicine and Biotechnology, Moscow, Russia

${ }^{3}$ Kursk State University, Kursk, Russia

${ }^{4}$ Chumakov Federal Scientific Center for Research and Development of Immune and Biological Products, Russian Academy of Sciences, Moscow, Russia

${ }^{5}$ Sechenov First Moscow State Medical University (Sechenov University), Moscow, Russia

Bakulev Center for Cardiovascular Surgery Moscow, Russia

7 Blokhin National Medical Research Center of Oncology, Moscow, Russia

${ }^{8}$ National Research University Higher School of Economics, Moscow, Russia

${ }^{9}$ Vavilov Institute of General Genetics, Moscow, Russia

${ }^{10}$ Plekhanov Russian University of Economics, Moscow, Russia

Noninvasive stable isotope breath tests allow highly accurate and safe estimation of liver and biliary tract function. The aim of this study was to test ${ }^{13} \mathrm{C}$-labeled linoleic and linolenic acids intended for diagnostic use for acute and subchronic toxicity. The acids were synthesized using the patented method. A single intragastric administration of the tested compounds to experimental BALB/c mice and Wistar rats in the amounts exceeding clinical doses 500 to 2500 -fold did not cause animal death. In the subchronic toxicity test, the rats received 5 to 25 times higher doses than recommended for clinical use in humans. In a 14 -day follow-up period, no significant differences were observed between the main and the control groups in terms of weight, blood count (red blood cells, white blood cells, platelets), and blood biochemistry (hemoglobin, total protein, alkaline phosphatase, alanine aminotransferase, aspartate aminotransferase, lactate dehydrogenase, bilirubin). The studied compounds are safe at doses intended for oral administration and are recommended for further preclinical and clinical trials.

Keywords: breath test, linoleic acid, linolenic acid, carbon-13

Funding: this study was part of the State Project 0112-2019-0001 on Genomic studies and genetic polymorphism of the cell, organism and population headed by Yankovsky NK.

Author contribution: Tynio YaYa, Morozova GV — synthesis of ${ }^{13} \mathrm{C}$-labeled linoleic acid; Biryukova YuK — blood biochemistry tests; Trubnikova EV — statistical analysis; Zylkova MV — preparation of histological slides; Sivokhin DA — literature analysis, manuscript draft; Ivanov KP — animal sacrifice and necropsy; Pozdniakova NV, Mutnykh ES - acute toxicity tests of ${ }^{13} \mathrm{C}$-labeled acids following their single administration; Kazakova EA — subchronic toxicity tests of ${ }^{13} \mathrm{C}$-labeled acids; Shevelev $\mathrm{AB}$ - study conception, analysis and discussion of its results.

Compliance with ethical standards: the study was approved by the regional Ethics Committee (Protocol № 3 dated February 26, 2018). Animal housing met the Sanitary and Epidemiological Requirements for Laboratory Animal Facilities (Guidelines 2.2.1.3218-14).

$\checkmark$ Correspondence should be addressed: Yulia K. Biryukova

Kosygina 4, Moscow, 119334; biriukova-ula@mail.ru

Received: 24.06.2019 Accepted: 28.06.2019 Published online: 30.06.2019

DOI: $10.24075 /$ brsmu.2019.044

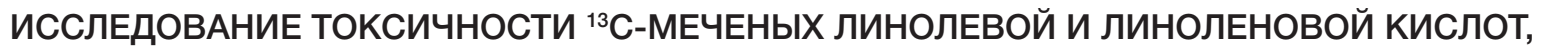 ПРЕДНАЗНАЧЕННЫХ ДЛЯ ПРОВЕДЕНИЯ ДИАГНОСТИЧЕСКИХ ДЫХАТЕЛЬНЫХ ТЕСТОВ}

Я. Я. Тыньо

Е. А. Казакова, Е. С. Мутных, А. Б. Шевелев ${ }^{9,10}$

${ }^{1}$ Российский государственный университет физической культуры, спорта, молодежи и туризма, Москва, Россия

2 Московская государственная академия ветеринарной медицины и биотехнологии имени К. И. Скрябина, Москва, Россия

${ }^{3}$ Курский государственный университет, Курск, Россия

${ }^{4}$ Федеральный научный центр исследований и разработки иммунологических препаратов имени М. П. Чумакова, Москва, Россия

${ }^{5}$ Первый Московский государственный медицинский университет имени И. М. Сеченова (Сеченовский Университет), Москва, Россия

${ }^{6}$ Национальный медицинский исследовательский центр сердечно-сосудистой хирургии имени А. Н. Бакулева, Москва, Россия

${ }^{7}$ Национальный медицинский исследовательский центр онкологии имени Н. Н. Блохина, Москва, Россия

${ }^{8}$ Национальный исследовательский университет Высшая школа экономики, Москва, Россия

${ }^{9}$ Институт общей генетики имени Н. И. Вавилова, Москва, Россия

${ }^{10}$ Российский экономический университет имени Г. В. Плеханова, Москва, Россия

Неинвазивные дыхательные тесты с применением изотопно-меченых соединений представляют собой новый высокоточный и безопасный метод функционального исследования печени и билиарной системы. Целью работы было провести биологические испытания острой и субхронической токсичности

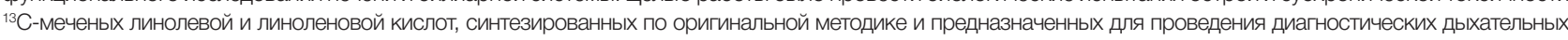
тестов. При однократном внутрижелудочном введении изучаемых соединений лабораторным мышам линии BALB/c и крысам Wistar в дозах, превышающих диагностические в 500-2500 раз, образцы соединений не вызывали смертности экспериментальных животных. При проведении субхронического эксперимента на крысах при дозировках испытываемых соединений, в 5 и 25 раз превышающих терапевтическую дозу для человека, в течение 14 суток было выявлено отсутствие достоверных изменений у животных в экспериментальных группах по сравнению с контрольной по массе тела, гематологическим показателям (содержанию эритроцитов, лейкоцитов и тромбоцитов в крови) и биохимическим показателям сыворотки крови (уровню гемоглобина, общего белка, щелочной фосфатазы, аланинаминотрансферазы, аспартатаминотрансферазы, лактатдегидрогеназы, билирубина). Исследованные меченые кислоты безвредны в дозах, планируемых для перорального введения, и могут быть рекомендованы к доклиническим и клиническим испытаниям.

Ключевые слова: дыхательный тест, линолевая кислота, линоленовая кислота, углерод-13

Финансирование: работа выполнена в рамках тематики Государственного задания № 0112-2019-0001 «Геномные исследования и генетический полиморфизм клетки, организма и популяции» (под руководством Н. К. Янковского).

Информация о вкладе авторов: Я. Я. Тыньо, Г. В. Морозова - наработка образцов меченой линолевой кислоты; Ю. К. Бирюкова - определение биохимических показателей сыворотки крови крыс; Е. В. Трубникова - статистическая обработка результатов; М. В. Зылькова - изготовление гистологических срезов; Д. А. Сивохин - обзор литературы, написание статьи; К. П. Иванов - забой крыс, патоморфологическое исследование

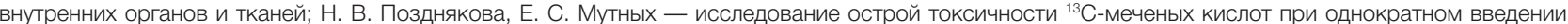

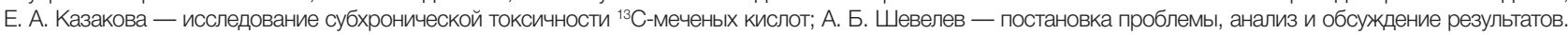
Соблюдение этических стандартов: исследование одобрено Региональным этическим комитетом (протокол № 3 от 26 февраля 2018 г.). Экспериментальных животных содержали в соответствии с действующими Санитарно-эпидемиологическими правилами СП 2.2.1.3218-14.

$\checkmark$ Для корреспонденции: Юлия Константиновна Бирюкова ул. Косыгина, д. 4, г. Москва, 119334; biriukova-ula@mail.ru

Статья получена: 24.06.2019 Статья принята к печати: 28.06.2019 Опубликована онлайн: 30.06.2019

DOI: $10.24075 /$ vrgmu.2019.044 
Breath tests are safe and effective tools that provide diagnostic information about the internal organs of the human body. The stable ${ }^{13} \mathrm{C}$ [1] and minimally radioactive ${ }^{14} \mathrm{C}$ [2] breath tests were introduced into clinical practice in the late $20^{\text {th }}$ century. Since then, they have become the gold standard in detecting Helicobacter pylori infection [3]. Urease abundantly produced by $\mathrm{H}$. pylori breaks down the urea taken in by the patient into ${ }^{13} \mathrm{CO}_{2}$ or ${ }^{14} \mathrm{CO}_{2}$ and ammonia. These products of urea hydrolysis are absorbed into the bloodstream and then excreted by the lungs [4]. The exhaled isotope-labeled $\mathrm{CO}_{2}$ can be measured using mass spectrometry or a Geiger-Mueller counter [5]. In the absence of $H$. pylori infection, the reaction described above does not occur, and the concentrations of the exhaled ${ }^{13} \mathrm{CO}_{2}$ or ${ }^{14} \mathrm{CO}_{2}$ do not fall outside the reference range.

Non-invasive breath tests are highly accurate, cheap, easy, and safe for both the doctor and the patient. They provide valuable information about a number of parameters needed to choose a treatment strategy [6].

So far, carbon isotopes have been employed as tracers in a variety of breath tests for assessing insulin resistance (those are based on ${ }^{13} \mathrm{C}$-glucose [7], ${ }^{13} \mathrm{C}$-metacetin [8], ${ }^{13} \mathrm{C}$-galactose and ${ }^{13} \mathrm{C}$-aminopyrine [9] ) and in the diagnosis of chronic liver diseases, including hepatitis $\mathrm{B}$ and $\mathrm{C}$, cirrhosis, toxic hepatitis, alcoholic hepatitis, etc. ${ }^{13} \mathrm{C}$-octanoic acid is used to measure the rate of gastric emptying [10], and $\left({ }^{13} \mathrm{C} 3\right.$-glyceryl) tri-octanoate helps in detecting exocrine pancreatic insufficiency [4].

We believe that extensive efforts taken to increase production output of carbon isotopes and create cost-effective equipment for measuring the isotopic composition of the exhaled breath will expedite introduction of such tests into clinical routine.

Linoleic and linolenic acids are the main active components used in breath tests designed to assess liver and biliary tract function. They are fatty acids with a carbon chain consisting of 18 carbon atoms. The acids are unsaturated: linoleic acid has two carbon-carbon bonds, whereas linolenic acid has three [11].

Tetrasodium pyrophosphate widely used in the production of radiopharmaceutical agents both in Russia and abroad serves as an excipient. In Russia, it was approved for medical applications by Order 507 of the Ministry of Healthcare dated April 14, 1985 (Certificate 85/507/13) and is now marketed as Pyrphotech ${ }^{99 m}$ Tc [12]. Pyrphotech has demonstrated good performance in bone scintigraphy, imaging of acute myocardial infarction, imaging of the choroid, angiocardiography, etc. $[12,13]$.

Patent 2630691 registered in Russia describes the original Method of synthesis of ${ }^{13} \mathrm{C}$ and ${ }^{14} \mathrm{C}$ linoleic and linolenic acids [14]; these fatty acids labeled with carbon isotopes are intended for use in breath tests that assess liver and biliary tract function. It is essential that therapeutic and diagnostic agents undergo a safety trial prior to being introduced into clinical practice. The aim of this work was to study acute and subchronic toxicity of ${ }^{13} \mathrm{C}$-labeled linoleic and linolenic acids.

\section{METHODS}

The acute toxicity test of linoleic and linolenic acids labeled with ${ }^{13} \mathrm{C}$ at position 1 was conducted in strict compliance with the Guidelines on the study of general toxicity of pharmacological agents [15]. The test was carried out in 95 male and female BALB/C mice weighing 18 to $20 \mathrm{~g}$ and 45 male and female Wistar rats weighing 180 to $210 \mathrm{~g}$.

The tested ${ }^{13} \mathrm{C}$-labeled acids were synthesized as described in the Method of synthesis of ${ }^{13} \mathrm{C}$ and ${ }^{14} \mathrm{C}$ linoleic and linolenic acids (Patent 2630691) [14]. The structure and purity of the intermediate and end products were assessed with nuclear magnetic resonance spectroscopy using an AM 300 spectrometer operating at $300 \mathrm{MHz}$ (Bruker; Germany) and a DRX-500 spectrometer operating at $500 \mathrm{MHz}$ (Bruker; Germany). Mass spectra were acquired using a directinfusion Finnigan MAT Model Incos 50, 70 eV (Finnigan MAT; UK) and a high-resolution mass spectrometer MicrOTOFII (BrukerDaltonics; Germany) (ESI).

The animals selected for the study were kept in T3 cages. Animal housing met the Sanitary and Epidemiological Requirements for Laboratory Animal Facilities. The animals had unlimited access to tap water supplied via $500 \mathrm{ml}$ glass bottles with stainless steel stoppers. The animals had a fixed meal schedule and were fed with pellets containing a balanced composition of amino acids, minerals and vitamins. Throughout the experiment, their physical activity, body weight, appetite, hair condition, and behavior were closely monitored.

For the acute toxicity test, the samples of the tested compounds were dissolved in olive oil and the freshly prepared solutions were administered to the animals by gavage. The rats received a single dose of 100 to $500 \mathrm{mg}$; the mice, a single dose of 10 to $50 \mathrm{mg}$. The follow-up period was 3 days. The lethal dose $\left(L_{50}\right)$ was determined for both BALB/c mice and Wistar rats using the Deichmann-LeBlanc method [15].

The subacute toxicity test of the synthesized isotope-labeled acids was conducted in 180 Wistar rats weighing 110-135 g. The test was performed in strict compliance with the Guidelines on the study of general toxicity of pharmacological agents [15]. The freshly prepared solutions of the tested compounds were fed to the animals by gavage at doses specified above every day for 2 weeks. The animals were distributed into several groups consisting of 15 males and 15 females each. Group 1 was the control group. The controls received olive oil that did not contain any of the tested acids. Group 2 received $5 \mathrm{mg} / \mathrm{kg}$ ${ }^{13} \mathrm{C}$-labeled linoleic acid, which is 5 times higher than the clinical dose in humans. Group 3 received $25 \mathrm{mg} / \mathrm{kg}{ }^{13} \mathrm{C}$-labeled linoleic acid, which is 25 times higher than the human clinical dose. Group 4 received 5 mg/kg ${ }^{13} \mathrm{C}$-labeled linolenic acid; this dose exceeds the human clinical dose 5-fold. Group 5 received $25 \mathrm{mg} / \mathrm{kg}{ }^{13} \mathrm{C}$-labeled linolenic acid, which exceeds the human clinical dose 5-fold.

In rats, blood samples (2.0-2.5 ml) were collected from the tail vein before the subchronic toxicity test, one week after the first administration of the tested compounds and 2 weeks after the first administration. Blood count was aided by a Picoscale PS-4M automated analyzer (Medicor-Elektromedika; Hungary).

Concentration of blood glucose, total protein, creatinine, cholesterol, total bilirubin, alkaline phosphatase, alanine aminotransferase, aspartate aminotransferase, and lactate dehydrogenase were determined using a discrete FP 901 analyzer (Labsystems; Finland).

The rats were sacrificed on day 14 of the subchronic toxicity experiment. Necropsy was performed straight away in order to avoid self-digestion of tissue by intracellular enzymes. A detailed report was prepared for each necropsy.

Specimens of organs and tissues were fixed in 10\% neutral buffered formalin, then dehydrated, cleared, and embedded in paraffin wax. Serial sections were prepared using a sliding MS-1 microtome (Ambimed; Russia). Upon deparaffinization, the sections were stained with hematoxylin-eosin, mounted in Canada balsam and covered with a coverslip. The obtained slides were examined under a Leica CM E microscope (Leica Microsystems; German) and photographed using a Micromed DCM-510 SCOPE eyepiece camera (Nabludatelnye pribory; Russia) at $\times 40, \times 100, \times 200$, and $\times 400$ magnification. Images 
were processed in the Future Win Joe software (Future Optics Chine) supplied with the eyepiece camera. Necropsy data were compared between the rats who had received ${ }^{13} \mathrm{C}$-labeled linoleic and linolenic acids and the controls.

The null hypothesis was tested using the nonparametric Mann-Whitney $U$ and Fisher exact tests in Statistica 8.0 for Windows (Dell; USA). Means, the median, maximum and minimum values and interquartile ranges were calculated [16]. For qualitative variables, the sampling fraction was calculated and expressed as percentage, as well as the sampling error.

\section{RESULTS}

\section{Study of acute single-dose toxicity of ${ }^{13} \mathrm{C}$-labeled linoleic and linoleic acids}

No signs of intoxication or gastric irritation were noticed in the animals following single administration of the tested compounds at the highest dose of $2.632 \mathrm{mg} / \mathrm{kg}$ for mice and $2.564 \mathrm{mg} / \mathrm{kg}$ for rats. No death cases were observed in both rats and mice. We found no differences in sensitivity to the compounds between the animals of different sex and species.

Thus, intragastric administration of ${ }^{13} \mathrm{C}$-labeled linoleic and ${ }^{13} \mathrm{C}$-labeled linolenic acids to small animal species at doses 2,500 times higher than the clinical dose in humans did not cause intoxication or animal death during the entire follow-up period ( 3 days). The manufacturer of ${ }^{13} \mathrm{C}$-labeled linoleic acid (Science Lab; USA) specifies that its $L D_{50}$ is $3.2 \mathrm{~g} / \mathrm{kg}$. This value was obtained after administering a significantly higher dose of the tested fatty acid to experimental animals. Therefore, we conclude that our acute toxicity test revealed no difference in toxicity between the acid synthesized by us and its commercially available analogue.

\section{Study of subchronic toxicity of ${ }^{13} \mathrm{C}$-labeled linoleic and linolenic acids in rats}

Two-week daily administration of 5 and $25 \mathrm{mg} / \mathrm{kg}{ }^{13} \mathrm{C}$-labeled linoleic and linolenic acids did not cause any significant changes in the animals' behavior and appearance, as compared to the controls. The animals were active, their hair was smooth and appetite was good.

Body weight dynamics monitored in all experimental and control groups throughout the experiment are presented in Tables 1 and 2.

On the whole, no significant differences were observed between the experimental and control groups except for the male group that was receiving 5 and $25 \mathrm{mg} / \mathrm{kg}{ }^{13} \mathrm{C}$-linolenic acid for 2 weeks. Those male rats were gaining more weight than the controls, which suggests a stimulatory effect of the tested compound on animal growth. No detrimental effect of the acid was observed on the growth and general health of the laboratory animals.

Results of blood tests in the experimental and control groups are shown in Table 3.

Slight yet significant differences (> 0.95 confidence level) in hemoglobin concentrations were revealed in the male rats who were receiving $5 \mathrm{mg} / \mathrm{kg}{ }^{13} \mathrm{C}$-linolenic acid. In the group of female rats who receiving the same dose of ${ }^{13} \mathrm{C}$-linolenic acid, the differences were significant for white blood cell and platelet

Table 1. Body weight dynamics of male rats that received ${ }^{13} \mathrm{C}$-labeled linoleic and linolenic acids by intragastric gavage for 2 weeks

\begin{tabular}{|c|c|c|c|}
\hline Before the experiment & Controls, $\mathrm{g}$ & Experimental group, $\mathrm{g}$ & $p$ \\
\hline Linoleic acid, $5 \mathrm{mg} / \mathrm{kg}$ & 113.3 & 115.7 & $>0.05$ \\
\hline Linoleic acid, 25 mg/kg & 113.3 & 114.0 & $>0.05$ \\
\hline \multicolumn{4}{|l|}{ Day 14 of the experiment } \\
\hline Linoleic acid, $5 \mathrm{mg} / \mathrm{kg}$ & 132.1 & 135.3 & $>0.05$ \\
\hline Linoleic acid, 25 mg/kg & 132.1 & 133.6 & $>0.05$ \\
\hline \multicolumn{4}{|l|}{ Before the experiment } \\
\hline Linolenic acid, 5 mg $/ \mathrm{kg}$ & 116.4 & 114.2 & $>0.05$ \\
\hline Linolenic acid, $25 \mathrm{mg} / \mathrm{kg}$ & 116.4 & 117.5 & $>0.05$ \\
\hline \multicolumn{4}{|l|}{ Day 14 of the experiment } \\
\hline Linolenic acid, 5 mg/kg & 130.6 & 136.3 & $>0.001$ \\
\hline Linolenic acid, 25 mg/kg & 130.6 & 138.2 & $<0.001$ \\
\hline
\end{tabular}

Table 2. Body weight dynamics of female rats that received ${ }^{13} \mathrm{C}$-labeled linoleic and linolenic acids by intragastric gavage for 2 weeks

\begin{tabular}{|l|c|c|c|}
\hline Before the experiment & Controls, $\mathrm{g}$ & Experimental group, $\mathrm{g}$ & $p$ \\
\hline Linoleic acid, $5 \mathrm{mg} / \mathrm{kg}$ & 111.9 & 112.2 & $>0.05$ \\
\hline Linoleic acid, $25 \mathrm{mg} / \mathrm{kg}$ & 111.9 & 112.9 & $>0.05$ \\
\hline Day 14 of the experiment & & & $>0.05$ \\
\hline Linoleic acid, $5 \mathrm{mg} / \mathrm{kg}$ & 129.3 & 132.1 & $>0.05$ \\
\hline Linoleic acid, $25 \mathrm{mg} / \mathrm{kg}$ & 129.3 & 131.5 & $>0.05$ \\
\hline Before the experiment & & & $>0.05$ \\
\hline Linolenic acid, $5 \mathrm{mg} / \mathrm{kg}$ & 113.8 & 115.4 & \\
\hline Linolenic acid, $25 \mathrm{mg} / \mathrm{kg}$ & 113.8 & 114.6 & $>0.05$ \\
\hline Day 14 of the experiment & & & $>05$ \\
\hline Linolenic acid, $5 \mathrm{mg} / \mathrm{kg}$ & 127.2 & 134.1 & \\
\hline Linolenic acid, $25 \mathrm{mg} / \mathrm{kg}$ & 127.2 & 130.3 & \\
\hline
\end{tabular}


counts. However, on day 14 of the experiment, the differences faded, which may suggest they were accidental.

By contrast, the end of week 1 revealed no significant differences between the groups that were receiving higher (25 mg/ $/ \mathrm{kg}$ ) doses of ${ }^{13} \mathrm{C}$-labeled linolenic acid. However, a significant decline in white blood cell count $>0.999$ confidence level) was noticed in the female rats on day 14 , as well as a slight decline in platelet count in both males and females

Table 3. Blood count in rats that received ${ }^{13} \mathrm{C}$-linoleic acid for 2 weeks
(> 0.95 confidence level). In spite of the differences between the groups, the absolute values of the measured parameters fell within the normal reference range, suggesting safety of the tested doses.

Total protein levels in the blood serum are given in Table 4.

The female rats who were receiving $5 \mathrm{mg} / \mathrm{kg}$ of the tested compound had higher total protein concentrations than the controls by the end of week 1 and week 2 . A similar situation

\begin{tabular}{|c|c|c|c|c|c|}
\hline \multicolumn{3}{|c|}{$5 \mathrm{mg} / \mathrm{kg}$} & \multicolumn{3}{|c|}{$25 \mathrm{mg} / \mathrm{kg}$} \\
\hline \multicolumn{6}{|c|}{ Red blood cells } \\
\hline & Males & Females & & Males & Females \\
\hline Week 1 & $p>0.05$ & $p>0.05$ & Week 1 & $p>0.05$ & $p<0.05$ \\
\hline Week 2 & $p>0.05$ & $p>0.05$ & Вторая неделя & $p>0.05$ & $p<0.05$ \\
\hline \multicolumn{6}{|c|}{ White blood cells } \\
\hline Week 1 & $p>0.05$ & $p<0.05$ & Week 1 & $p>0.05$ & $p>0.05$ \\
\hline Week 2 & $p>0.05$ & $p>0.05$ & Week 2 & $p>0.05$ & $p=0.001$ \\
\hline \multicolumn{6}{|c|}{ Platelets } \\
\hline Week 1 & $p>0.05$ & $p<0.05$ & Week 1 & $p>0.05$ & $p>0.05$ \\
\hline Week 2 & $p>0.05$ & $p>0.05$ & Week 2 & $p<0.05$ & $p<0.05$ \\
\hline \multicolumn{6}{|c|}{ Hemoglobin } \\
\hline Week 1 & $p<0.05$ & $p>0.05$ & Week 1 & $p>0.05$ & $p>0.05$ \\
\hline Week 2 & $p>0.05$ & $p>0.05$ & Week 2 & $p>0.05$ & $p>0.05$ \\
\hline
\end{tabular}

Table 4. Total protein concentrations $(\mathrm{g} / \mathrm{L})$ in the blood serum of rats that received ${ }^{13} \mathrm{C}$-linoleic acid for 2 weeks

\begin{tabular}{|c|c|c|c|c|c|}
\hline \multicolumn{3}{|c|}{$5 \mathrm{mg} / \mathrm{kg}$} & \multicolumn{3}{c|}{$25 \mathrm{mg} / \mathrm{kg}$} \\
\hline & Males & Females & & Males & Females \\
\hline Week 1 & $p>0.05$ & $p<0.05$ & Week 1 & $p>0.05$ & $p<0.05$ \\
\hline Week 2 & $p<0.05$ & $p<0.05$ & Week 2 & $p<0.05$ & $p>0.05$ \\
\hline
\end{tabular}

Table 5. Enzymic activity and total bilirubin levels in the blood serum of male rats that received ${ }^{13} \mathrm{C}$-linoleic acid for 2 weeks

\begin{tabular}{|c|c|c|c|c|c|}
\hline \multicolumn{3}{|c|}{$5 \mathrm{mg} / \mathrm{kg}$} & \multicolumn{3}{|c|}{$25 \mathrm{mg} / \mathrm{kg}$} \\
\hline \multicolumn{6}{|c|}{ Alkaline phosphatase } \\
\hline & Males & Females & & Males & Females \\
\hline Week 1 & $p>0.05$ & $p<0.05$ & Week 1 & $p<0.01$ & $p<0.01$ \\
\hline Week 2 & $p<0.05$ & $p<0.05$ & Week 2 & $p<0.001$ & $p<0.01$ \\
\hline \multicolumn{6}{|c|}{ Alanine aminotransferase, un/L } \\
\hline Week 1 & $p>0.05$ & $p<0.05$ & Week 1 & $p<0.001$ & $p<0.001$ \\
\hline Week 2 & $p<0.05$ & $p<0.05$ & Week 2 & $p>0.05$ & $p>0.05$ \\
\hline \multicolumn{6}{|c|}{ Aspartate aminotransferase, un/L } \\
\hline Week 1 & $p>0.05$ & $p>0.05$ & Week 1 & $p<0.05$ & $p>0.05$ \\
\hline Week 2 & $p<0.001$ & $p<0.01$ & Week 2 & $p>0.05$ & $p>0.05$ \\
\hline \multicolumn{6}{|c|}{ Lactate dehydrogenase, un/L } \\
\hline Week 1 & $p>0.05$ & $p<0.001$ & Week 1 & $p<0.001$ & $p<0.001$ \\
\hline Week 2 & $p<0.001$ & $p<0.001$ & Week 2 & $p<0.001$ & $p<0.001$ \\
\hline \multicolumn{6}{|c|}{ Total bilirubin, $\mu \mathrm{M}$} \\
\hline Week 1 & $p<0.001$ & $p<0.01$ & Week 1 & $p<0.001$ & $p<0.001$ \\
\hline Week 2 & $p>0.05$ & $p<0.001$ & Week 2 & $p<0.001$ & $p<0.001$ \\
\hline
\end{tabular}


was observed in the male rats on day 14 of the experiment. As compared to the controls, total protein levels were also higher in the female rats a week after the onset of the experiment and in the male animals on day 14 . This suggests that the studied compound stimulates protein synthesis, which cannot be regarded as a sign of its toxic effect.

Hepatotoxicity of candidate drugs is traditionally inferred from elevated aspartate and alanine aminotransferases, alkaline phosphatase, lactate dehydrogenase, and total bilirubin in the blood serum (Table 5).

In week one, we witnessed a slight decline in hepatic enzymes in the animals who were receiving $5 \mathrm{mg} / \mathrm{kg}{ }^{13} \mathrm{C}$-linoleic acid. During week 2, this decline became significant in all the subjects. A drop in alkaline phosphatase was the most pronounced for $25 \mathrm{mg} / \mathrm{kg}$ doses. By contrast, the levels of aminotransferases had gone back to normal by the end of week 2.

Administered at 5 and $25 \mathrm{mg} / \mathrm{kg},{ }^{13} \mathrm{C}$-linoleic acid caused a significant decline in total bilirubin measured in the blood serum during weeks 1 and 2 of the experiment (except for the group of male rats during week 2 ). This observation suggests that the tested compound is not toxic to the liver and possibly has a hepatoprotective effect.

\section{DISCUSSION}

It is hard to assess the feasibility of breath tests in small laboratory animals because collection of exhaled air samples is a technically demanding procedure. Therefore, we plan to conduct the efficacy and safety trials of ${ }^{13} \mathrm{C}$-linoleic and ${ }^{13} \mathrm{C}$-linolenic acids in human patients once the acids successfully pass extensive toxicity studies. A similar strategy was adopted by other researchers who developed $a{ }^{14} \mathrm{C}$ urea breath test for detecting $H$. pylori infection [2].

Acute toxicity tests of ${ }^{13} \mathrm{C}$-linoleic and ${ }^{13} \mathrm{C}$-linolenic acids administered to BALB/c mice and Wistar rats as a single oral dose that exceeds the clinical dose in humans 500 to 2,500-fold did not reveal any signs of general toxicity or gastric irritation. No death cases were observed.

The study of subchronic toxicity of ${ }^{13} \mathrm{C}$-linoleic acid administered to male and female Wistar rats at 5 and $25 \mathrm{mg} / \mathrm{kg}$, which is 5 and 25 times higher than the clinical dose in humans, on a daily basis for 2 weeks did not reveal any pronounced effect of the acids on the general health, activity and behavior of the animals.

Moreover, at such high doses the acids produced a beneficial effect on the animals reflected in their blood count and blood chemistry. White blood cells and platelets underwent a transient decline in their number but the counts were still within the normal reference range. A transient decline was also observed for alkaline phosphatase, alanine aminotransferase, aspartate aminotransferase, lactate dehydrogenase, and bilirubin. Those effects were dose-dependent, suggesting that they will be further reduced to zero at clinical doses. There are reports of similar effects observed for linoleic and linolenic acids not labeled with carbon isotopes [17].

\section{CONCLUSIONS}

${ }^{13} \mathrm{C}$-labeled linoleic and ${ }^{13} \mathrm{C}$-labeled linolenic acids synthesized following the original method described in Patent 2630691 (Russia) are safe for laboratory animals at doses intended for oral intake and can be recommended for further preclinical and clinical trials.

\section{References}

1. Savarino V, Vigneri S, Celle G. The ${ }^{13} \mathrm{C}$ urea breath test in the diagnosis of Helicobacter pylori infection. Gut. 1999; 45 (suppl. 1): 18-23.

2. Balãn $\mathrm{H}$, Gold $\mathrm{CA}$, Dworkin HJ, McCormick VA, Freitas JE Procedure Guideline for Carbon-14-Urea Breath Test. J Nucl Med. 2016; 39 (11): 2012-14.

3. Zhou Q, Li L, Ai Y, Pan Z, Guo M, Han J. Diagnostic accuracy of the ${ }^{14} \mathrm{C}$-urea breath test in Helicobacter pylori infections: a metaanalysis. Wien Klin Wochenschr. 2017; 129 (1-2): 38-45.

4. Elman AR, Rapoport SI. Stabil'no-izotopnaja diagnostika v Rossii: itogi i perspektivy. ${ }^{13}$ S-preparaty, pribory, metody. Klin. med. 2014; 92 (7): 5-11. Russian.

5. Modak AS. Stable isotope breath tests in clinical medicine: A review. J Breath Res. 2007; 1 (1): R1-R13.

6. Musialik J, Jonderko K, Kasicka-Jonderko A, Buschhaus M. ${ }^{13} \mathrm{CO}_{2}$ breath tests in non-invasive hepatological diagnosis. Prz. Gastroenterol. 2015; 10 (1): 1-6.

7. Mizrahi M, Lalazar G, Adar T, Raz I, Ilan Y. Assessment of insulin resistance by a ${ }^{13} \mathrm{C}$ glucose breath test: A new tool for early diagnosis and follow-up of high-risk patients. Nutr J. 2010; (9): 25. DOI:10.1186/1475-2891-9-25.

8. Elman AR, Korneeva GA, Noskov YuG, Khan VN, Shishkina EYu, Negrimovski VM, i dr. Sintez produktov, mechennyh izotopom ${ }^{13} \mathrm{~S}$, dlja medicinskoj diagnostiki. Rossijskij himicheskij zhurnal. 2013; LVII (5-2): 3-24. Rssian.

9. Giannini EG, Alberto F, Paolo B, Federica B, Federica M. ${ }^{13} \mathrm{C}$-galactose breath test and ${ }^{13} \mathrm{C}$-aminopyrine breath test for the study of liver function in chronic liver disease. Clin Gastroenterol Hepatol. 2005; 3 (3): 279-85.
10. Horowitz M, O'Donovan D, Jones KL, Feinle C, Rayner CK, Samsom M. Gastric emptying in diabetes: Clinical significance and treatment. Diabet Med. 2002; 19 (3): 177-94.

11. Titov VN. Klinicheskaja biohimija zhirnyh kislot, lipidov i lipoproteinov. Gipolipidemicheskaja terapija i profilaktika ateroskleroza. Klinikolaboratornyj konsilium. 2014; (1): 4-29. Russian.

12. Malysheva AO, Kodina GE, Voronitckaya NN, Grafskova TA, Semonenko NP. Opredelenie kachestva radiofarmacevticheskogo preparata «Pirfoteh, 99m Tc» v medicinskih uchrezhdenijah. MOBI-HimFarma. 2017; s. 103. Available from: http://mobi-chem. org/arhiv.html. Russian.

13. Sazonova SI, llyushenkova YuN, Lishmanov YuB. Metodika radionuklidnogo issledovanija vospalitel'nyh processov v serdce. Sibirskij medicinskii zhurnal 2015; 30 (4): 32-5. Russian.

14. Pozdeev W, Tyno YYa, Morozova GV, Bychenko AB, Biryukova YuK, Shevelev AB, avtory; OOO «GK NASh MIR»(RU), patentoobladatel'. Synthesis method of linoleum and linolenic acids, marked by carbon compunds ${ }^{13} \mathrm{C}$ and ${ }^{14} \mathrm{C}$. Patent RF № 2630691. 12.09.2017

15. Habriev RU. Rukovodstvo po jeksperimental'nomu (doklinicheskomu) izucheniju novyh farmakologicheskih veshhestv. M.: Medicina, 2005. 832 s. Russian

16. Rebrova OYu. Statisticheskij analiz medicinskih dannyh. Primenenie paketa prikladnyh programm STATISTICA. M.: MediaSfera, 2003. 312 s. Russian

17. Teng H, Lin Q, LiK, Yuan B, Song H, Peng H, et al. Hepatoprotective effects of raspberry (Rubus coreanus Miq.) seed oil and its major constituents. Food Chem Toxicol. 2017; (110): 418-24. 


\section{Литература}

1. Savarino V, Vigneri S, Celle $\mathrm{G}$. The ${ }^{13} \mathrm{C}$ urea breath test in the diagnosis of Helicobacter pylori infection. Gut. 1999; 45 (suppl. 1): 18-23.

2. Balãn H, Gold CA, Dworkin HJ, McCormick VA, Freitas JE. Procedure Guideline for Carbon-14-Urea Breath Test. J Nucl Med. 2016; 39 (11): 2012-14.

3. Zhou Q, Li L, Ai Y, Pan Z, Guo M, Han J. Diagnostic accuracy of the ${ }^{14} \mathrm{C}$-urea breath test in Helicobacter pylori infections: a metaanalysis. Wien Klin Wochenschr. 2017; 129 (1-2): 38-45.

4. Эльман А. Р., Рапопорт С. И. Стабильно-изотопная диагностика в России: итоги и перспективы. ${ }^{13} \mathrm{C}$-препараты, приборы, методы. Клин. мед. 2014; 92 (7): 5-11.

5. Modak AS. Stable isotope breath tests in clinical medicine: A review. J Breath Res. 2007; 1 (1): R1-R13.

6. Musialik J, Jonderko K, Kasicka-Jonderko A, Buschhaus M. ${ }^{13} \mathrm{CO}_{2}$ breath tests in non-invasive hepatological diagnosis. Prz. Gastroenterol. 2015; 10 (1): 1-6.

7. Mizrahi M, Lalazar G, Adar T, Raz I, Ilan Y. Assessment of insulin resistance by a ${ }^{13} \mathrm{C}$ glucose breath test: A new tool for early diagnosis and follow-up of high-risk patients. Nutr J. 2010; (9): 25. DOI:10.1186/1475-2891-9-25.

8. Эльман А. Р., Корнеева Г. А., Носков Ю. Г., Хан В. Н., Шишкина Е. Ю., Негримовски В. М. и др. Синтез продуктов, меченных изотопом ${ }^{13} \mathrm{C}$, для медицинской диагностики. Российский химический журнал. 2013; LVII (5-2): 3-24

9. Giannini EG, Alberto F, Paolo B, Federica B, Federica M. ${ }^{13} \mathrm{C}$-galactose breath test and ${ }^{13} \mathrm{C}$-aminopyrine breath test for the study of liver function in chronic liver disease. Clin Gastroenterol Hepatol. 2005; 3 (3): 279-85.

10. Horowitz M, O'Donovan D, Jones $\mathrm{KL}$, Feinle C, Rayner CK,
Samsom M. Gastric emptying in diabetes: Clinical significance and treatment. Diabet Med. 2002; 19 (3): 177-94.

11. Титов В. Н. Клиническая биохимия жирных кислот, липидов и липопротеинов. Гиполипидемическая терапия и просилактика атеросклероза. Клинико-лабораторный консилиум. 2014; (1): 4-29.

12. Малышева А. О., Кодина Г. Е., Вороницкая Н. Н., Графскова Т. А., Семоненко Н. П. Определение качества радиофармацевтического препарата «Пирфотех, 99m Тс» в медицинских учреждениях. МОБИ-ХимФарма. 2017; с. 103. Доступно по ссылке: http://mobi-chem.org/arhiv.html.

13. Сазонова С. И., Ильюшенкова Ю. Н., Лишманов Ю. Б. Методика радионуклидного исследования воспалительных процессов в сердце. Сибирский медицинский журнал 2015; $30(4): 32-5$

14. Поздеев В. В., Тыньо Я. Я., Морозова Г. В., Быченко А. Б., Бирюкова Ю. К., Шевелев А. Б., авторы; ООО "ГК"НАШ MИP"(RU), патентообладатель. Способ синтеза линолевой и линоленовой кислот, меченных изотопами углерода ${ }^{13} \mathrm{C}$ и ${ }^{14} \mathrm{C}$. Патент РФ № 2630691. 12.09.2017.

15. Хабриев Р. У. Руководство по экспериментальному (доклиническому) изучению новых фармакологических веществ. М.: Медицина, 2005. 832 с.

16. Реброва О. Ю. Статистический анализ медицинских данных. Применение пакета прикладных программ STATISTICA. M. МедиаСфера, 2003. 312 c.

17. Teng H, Lin Q, Li K, Yuan B, Song H, Peng H, et al. Hepatoprotective effects of raspberry (Rubus coreanus Miq.) seed oil and its major constituents. Food Chem Toxicol. 2017; (110): 418-24. 